\title{
Sexual Behavior of Female Sex Workers in Makassar, Indonesia
}

\author{
M.Akbar Alwi ${ }^{1}$, Hadzmawaty Hamzah ${ }^{2}$, Ulfah Mahfudah ${ }^{3}$ \\ ${ }^{1,2,3}$ Faculty of Health, Patria Artha University, Makassar, Indonesia \\ Corresponding Author: M.Akbar Alwi
}

\begin{abstract}
Introduction: Sexual workers have been considered a core group for HIV and Sexual Transmission Diseases (STDs). Their risk is higher than women in the general population. As a developing country, Indonesia is no exception, where sexual transmission has become the main driver for the development of the epidemic in recent years. The survey result of Makassar's AIDS Eradication Commission in 2014 showed that the number of FSWs in Makassar increased. The high number of FSWs in Makassar affects the number of HIV/AIDS cases apparently.

Method: This study used data from a rapid survey conducted by Makassar AIDS Eradication Commission in 2013. The survey was carried out to gain information about the sexual behaviour of FSWs in Makassar. The number of sample was 240 in which sampling was carried out using the C-Survey program system. A systematic questionnaire was used to gather data from FSWs, and data was analyzed by using STATA program.

Result: Most of the FSWs in this study are aged between $36-40$ years old (27.9\%). For the last sexual intercourse, most of the FSWs offered a condom to their clients $(85.0 \%)$. However, the number of clients who used a condom for intercourse was lower that is $77.5 \%$. The main reason why clients refuse to use a condom is that they are uncomfortable.
\end{abstract}

Conclusion: The awareness of FSWs to offer a condom is higher than the willingness of clients to use a condom consistently.

Keywords: Sexual Behaviour; Condom Use; Female Sexual Workers; Makassar.

\section{INTRODUCTION}

Female sex workers (FSWs) are at high risk of mortality and morbidity related to their sexual behaviours, and they are also at risk of sexually transmitted infections (STIs), including HIV (1). FSWs are 13.5 times more likely to be infected with HIV compared to the general female population(2). Based on the effectiveness of consistent condom use for preventing the transmission of HIV and other sexually transmitted infections (STI)(3-8), numerous countries have adopted intervention programs for FSW that focus on increasing condom use as a central strategy(9). Despite these efforts, as of 2012, the average HIV prevalence among FSW in 50 low and middle-income countries was $11.8 \%$ and 15 of these countries had FSW HIV prevalence over $23 \%(2)$.

Sexual workers have been considered a core group for HIV and STIs transmission. FSWs may have several sexual partners, including regular, casual, and paying sexual clients, including concurrent sexual partners. Besides the type of sexual partners, they may adopt practices that jeopardize their health, such as improper and inconsistent condom usage with a client(10). Moreover, sex workers often have little control over these factors because of social marginalization and criminalized work environments. Alcohol, drug use, and violence in some settings may further exacerbate their vulnerability and risk(11). 
As a developing country, Indonesia is no exception, where sexual transmission has become the primary driver for the development of the epidemic in recent years. The average nationwide HIV prevalence in Indonesia is $0.4 \%(0.1-3.5 \%)$ (12). The burden of HIV in the nation is higher among the most at-risk populations (MARPS), including the Female Sex Workers (FSWs), men who have sex with men (MSM) and people who inject drugs (12). Based on the data of Ministry of health, the number of HIV/AIDS in Indonesia on the general population tends to fluctuate. In 2019, the number of HIV and AIDS cases was 50.282 and 7.036, respectively(13). The number spreads in some regions in Indonesia including in Makassar.

As a capital of South Sulawesi, Makassar is the fourth biggest city in Indonesia, and the biggest one in the East of Indonesia, with a population in 2019 was 1.526.677 people(14). Makassar is growing rapidly in various fields both physical and social. It causes either a positive effect or a negative effect. In addition, the growth is followed by encouraging people to come to Makassar to look for a job in various sectors including working as a female sex worker. The survey result of Makassar's AIDS Eradication Commission in 2014 showed that the number of FSWs in Makassar increased to 1.789 people. The high number of FSWs in Makassar affects the number of HIV/AIDS cases apparently. As a big and metropolitan city, Makassar has the highest number of HIV/AIDS in South Sulawesi Province. In 2015 in Makassar, the finding of a new case of HIV is 655 cases consisted of 451 males and 214 females(15). Several studies about condom usage and sexual behavior on female sex workers in Makassar have conducted. However, the information about this issue should be updated to know the current situation of public health issues, especially on specific population that is female sexual workers. The aim of this study was to provide an understanding of the current sexual practices and other health issues of FSW in Makassar.

\section{METHODS}

This study used data from a rapid survey conducted by Makassar AIDS Eradication Commission. The survey was carried out in 2013 to gain information about sexual behaviour of FSWs in Makassar. Data was collected by using a systematic questionnaire that consists of characteristics of respondents and their sexual behaviour especially for condom usage. Some enumerators were trained for data collection and interview. FSWs were interviewed in the evening to the night in some bars and brothels because FSWs start doing their job in the evening. Sampling was carried out using the C-Survey program system. The direct FSW data based on the 2011 mapping results were entered in the CSurvey program and then systemically randomized. The number of sample in this study was 240 FSWs that spread in some locations:

Table 1: Number of Sample for Each Locations

\begin{tabular}{|c|l|c|}
\hline No. & \multicolumn{1}{|c|}{ Location/Hotspot } & $\begin{array}{c}\text { Number of } \\
\text { Respondents }\end{array}$ \\
\hline 1 & Mirama Bars & 24 \\
\hline 2 & Nusa Dua Bars & 32 \\
\hline 3 & Makassar Pub & 24 \\
\hline 4 & Rimadona Bars & 16 \\
\hline 5 & Raja Mas Bars & 24 \\
\hline 6 & Pondok Wisata & 8 \\
\hline 7 & Bordil Jenber & 16 \\
\hline 8 & Bordil Adipura & 8 \\
\hline 9 & Bordil Sungai Limboto & 32 \\
\hline 10 & Bordil Daya & 16 \\
\hline 11 & Jalan Sumba (street) & 16 \\
\hline 12 & Jalan Veteran (street) & 16 \\
\hline 13 & Jalan Sungai Saddang (street) & $\mathbf{2 4 0}$ \\
\hline & Jumlah & \\
\hline
\end{tabular}

\section{RESULT}

There were 240 respondents who participated in this study. Characteristics of respondents of this study consist of age, education and length of working as a sex worker. Most of the respondents aged between 36-40 years old (27.9\%). Meanwhile, the percentage of FSWs aged > 40 was 7.9. In terms of education, the vast majority of respondents completed their education from primary school (35.4\%) and 
there is only 1 respondent who graduated from an Academy (Diploma). Meanwhile, there were $7.5 \%$ of FSWS did not have a formal education (Table 2).

Table 2: Characteristics of Female Sex Workers (FSWs) in Makassar, 2013

\begin{tabular}{|l|c|c|}
\hline \multicolumn{1}{|c|}{ Characteristics } & N (240) & \% \\
\hline Age & & \\
\hline $18-25$ & 42 & 17.5 \\
\hline $26-30$ & 52 & 21.7 \\
\hline $31-35$ & 60 & 25.0 \\
\hline $36-40$ & 67 & 27.9 \\
\hline$>40$ & 19 & 7.9 \\
\hline Education & & \\
\hline Never attended school & 18 & 7.5 \\
\hline Primary & 85 & 35.4 \\
\hline Junior High School & 82 & 34.2 \\
\hline Secondary High School & 54 & 22.5 \\
\hline Academy (Diploma) & 1 & 0.4 \\
\hline Length of Working as FSWs (Years) & & \\
\hline$<$ I & 62 & 25.8 \\
\hline $1-3$ & 122 & 50.8 \\
\hline $4-6$ & 32 & 13.3 \\
\hline $7-9$ & 13 & 5.4 \\
\hline$>9$ & 11 & 4.6 \\
\hline & &
\end{tabular}

For the last sexual intercourse, most of the FSWs offered a condom to their clients $(85.0 \%)$. However, the number of clients who used condom for intercourse was lower that is $77.5 \%$. For the availability of condoms, the vast majority $(77.1 \%)$ of FSWs said that condoms were available and their clients used it. However, there were $15.0 \%$ of clients who did not use condoms although condoms were available. Most of the FWSs were aware of providing condoms for their client (67.1). Moreover, there were $5.8 \%$ of clients also provided condoms by their selves. In the last week, most FSWs provided a service to customers between 5 to 9 clients $(30.0 \%)$, and there were $15.4 \%$ of FSWs who serviced around $>19$ guests. For those who did not use a condom last week, uncomfortable is the most reason for them $(57.9 \%)$, and there were $3,8 \%$ of clients who did not use a condom because they threatened to cancel the sexual transaction (Table 3).

Table 3: Sexual Behavior of Female Sex Workers (FSWs) in Makassar, 2013
\begin{tabular}{|l|c|c|}
\hline \multicolumn{1}{|c|}{ Sexual Behavior } & N $(240)$ & $\%$ \\
\hline Offering a condom to the last sexual intercourse & & \\
\hline Yes & 204 & 85.0 \\
\hline No & 36 & 15.0 \\
\hline Using a condom for the last sexual intercourse & 186 & 77.5 \\
\hline Yes & 54 & 22.5 \\
\hline No & & \\
\hline Availability of Condom in the last sexual intercourse & 19 & 7.9 \\
\hline Unavailable & 36 & 15.0 \\
\hline Available but not using condom & 185 & 77.1 \\
\hline Available and using a condom & & \\
\hline Who provides condom in the last sexual intercourse & 161 & 67.1 \\
\hline FSWs & 46 & 19.2 \\
\hline Pimp or manager brothel & 14 & 5.8 \\
\hline Clients & 19 & 7.9 \\
\hline Condom is not available & & \\
\hline Number of Clients in the last week (persons) & 63 & 26.2 \\
\hline$<5$ & 72 & 30.0 \\
\hline $5-9$ & 38 & 15.8 \\
\hline $10-14$ & 30 & 12.5 \\
\hline $15-19$ & 37 & 15.4 \\
\hline$>19$ & & \\
\hline Reason no using condom in the last week & 139 & 57.9 \\
\hline Uncomfortable & 28 & 11.7 \\
\hline Clients insist not to use a condom & 9 & 3.0 \\
\hline Clients pay more & 35 & 14.6 \\
\hline Clients threaten to cancel & 41 & 17.1 \\
\hline Clients are regular guests & & \\
\hline Others & & \\
\hline
\end{tabular}

\section{DISCUSSION}

This study interviewed 240 Female sex workers as a respondent to collect information on their sexual behavior and condom usage of their clients. This study suggested that most of the respondents are productive age that was between $36-40$ years. They mostly have a low education (primary and junior high school) with an average length of working in the sex industry of 1 to 3 years. 
This finding differed from a study in Rwanda (10) within three years (2006, 2010, 2015). The study suggested that most of FSWS are younger (20-24 years old). Several studies in Korea, Bangladesh, and Zimbabwe also suggested that most FSWs were in young age (25-35 years old) $(1,16,17)$. Meanwhile, for education level, studies found that vast majority of FSWs were in low education $(1,16,17)$ that similar our finding in Makassar, Indonesia. Low education could be one of the reasons why they choose to be a sex worker.

This study revealed that awareness of FSWs to offer condoms to client was very good. However, the awareness of FSWs was not supported by clients, where the percentage of clients used condom in the last sexual intercourse lower than the percentage of FSWs who offered condom to them. Moreover, although condoms are available at the time, clients still kept not using a condom. A similar result in Australia founded that consistent condom use with all clients was high (97.1\%) among FSWs, especially for vaginal and anal sex (18). Meanwhile, studies in several countries revealed a lower consistent condom usage than in Makassar. A study in China founded $50.5 \%$ of the respondents always used condoms with clients over the previous month(19). A qualitative study in Iran suggested condom usage of clients was very low(20). The high percentage of condom use among clients in Makassar showed the success of Makassar AIDS Eradication Commission in conducting a condom promotion program and provides information about how to prevent HIV/AIDS and other STDs. A condom should be used consistently by FSWs because they provide a service to many clients. In addition, the risk of FSWs being infected HIV is higher than women in the general population. Most condoms are highly effective in preventing HIV and certain other sexually transmitted diseases (STDs). Condoms help prevent HIV for higher-risk sexual activities like anal or vaginal sex and lower-risk activities like oral sex and sharing sex toys(21). A reexamination of HIV seroconversion studies revealed that condoms are 90 to $95 \%$ effective when used consistently, i.e. consistent condom users are 10 to 20 times less likely to become infected when exposed to the virus than are inconsistent or nonusers. Similar results are obtained utilizing model-based estimation techniques, which indicate that condoms decrease the percontact probability of male-to-female transmission of HIV by about $95 \%$ (5).

Our finding in Makassar revealed several reasons why clients refused to use a condom. Mostly they said that they were uncomfortable. This finding was similar to a qualitative study in Indonesia suggested that clients refuse to use condoms because most of them cannot enjoy sexual intercourse, as condoms feel slippery and cold(22). This finding was inconsistent with a study in Brazil in 2019, a low education level is the main factor of clients why they refuse to use condom(23). A study in Uganda showed that low sexual control by FSWs increases inconsistent use by regular clients(24).

The other reasons why clients of FSWs in Makassar refuse to use condom are that the clients are regular partners, some clients insist not to use, clients pay more, and they threaten to cancel the sex activity. Some studies founded that women sex workers have less power to negotiate to clients to ask them use a condom. If clients refuse to use a condom, FSWs still provide service to them because they need to earn money for a living. A systematic review of literature in Asia [7] revealed factors that determined the ability of FSWs to negotiate condom use: individual-level factors such as sex workers' knowledge, perception, and power; interpersonal and environmental level factors including dynamics with clients and peer-related factors; and other factors such as access resources, poverty, stigma, the legal barrier and the role of media(25).

The result of this study could be a reference to determine the right prevention program to avoid the spreading of HIV 
among FSWs in Makassar. This study only provides a description of the information about sexual behaviour and condom use among FSWs in Makassar. Further research could be conducted to analyze factors that increase consistent condom use among clients in Makassar.

\section{CONCLUSION}

FSWS in this study have good awareness to offer condom to clients, and consistent condom use among clients is high. Condom promotion programs should focus on FSWs and clients to increase their performance in using condoms consistently.

\section{REFERENCES}

1. Wahed T, Alam A, Sultana S, Alam N, Somrongthong R. Sexual and reproductive health behaviors of female sex workers in Dhaka, Bangladesh. PLoS One. 2017;12 (4):e0174540.

2. Baral S, Beyrer C, Muessig K, Poteat T, Wirtz AL, Decker MR, et al. Burden of HIV among female sex workers in low-income and middle-income countries: a systematic review and meta-analysis. Lancet Infect Dis. 2012;12(7):538-49.

3. Weller SC, Davis-Beaty K. Condom effectiveness in reducing heterosexual HIV transmission. Cochrane database Syst Rev. 2002;(1).

4. Davis KR, Weller SC. The effectiveness of condoms in reducing heterosexual transmission of HIV. Fam Plann Perspect. 1999;272-9.

5. Pinkerton SD, Abramson PR. Effectiveness of condoms in preventing HIV transmission. Soc Sci Med. 1997;44 (9):1303-12.

6. Holmes KK, Levine R, Weaver M. Effectiveness of condoms in preventing sexually transmitted infections. Bull World Health Organ. 2004;82:454-61.

7. Weller SC. A meta-analysis of condom effectiveness in reducing sexually transmitted HIV. Soc Sci Med. 1993;36 (12):1635-44.

8. Wald A, Langenberg AGM, Link K, Izu AE, Ashley R, Warren T, et al. Effect of condoms on reducing the transmission of herpes simplex virus type 2 from men to women. Jama. 2001;285(24):3100-6.
9. Wariki WM V, Ota E, Mori R, Koyanagi A, Hori N, Shibuya K. Behavioral interventions to reduce the transmission of HIV infection among sex workers and their clients in low-and middle-income countries. Cochrane Database Syst Rev. 2012;(2).

10. Mutagoma M, Nyirazinyoye L, Sebuhoro D, Riedel DJ, Ntaganira J. Sexual risk behaviors and practices of female sex workers in Rwanda in over a decade, 20062015. Int J STD AIDS. 2018;29 (13):131623.

11. World Health Organization (WHO). Prevention and Treatment of HIV and Other Sexually Transmitted Infections for Sex Workers in Low-and Middle-Income Countries: Recommendations for a Public Health Approach. 2012; (December):52. Available from: http://apps.who.int/iris/bitstream/10665/777 45/1/9789241504744_eng.pdf

12. WHO. Review of the National Health Sector Response to HIV in the Republic of Indonesia: Report 2017. Geneva, Switzerland; 2017.

13. KEMENKES RI. Infodatin HIV AIDS. Kesehatan [Internet]. 2020;1-8. Available from: http://www.depkes.go.id/resources/downloa d/pusdatin/infodatin/Infodatin AIDS.pdf

14. BPS. Makassar Municipality in Figures 2018. 2018.

15. Dinas Kesehatan. Profil Kesehatan Kota Makassar 2015. Makassar; 2015.

16. Jung M. Risk factors of sexually transmitted infections among female sex workers in Republic of Korea. Infect Dis poverty. 2019;8(1):1-8.

17. Chabata ST, Hensen B, Chiyaka T, Mushati P, Mtetwa S, Hanisch D, et al. Changes over time in HIV prevalence and sexual behaviour among young female sex-workers in 14 sites in Zimbabwe, 2013-2016. AIDS Behav. 2019;23 (6):1494-507.

18. Zappulla A, Fairley CK, Donovan B, Guy $\mathrm{R}$, Bradshaw CS, Chen MY, et al. Sexual practices of female sex workers in Melbourne, Australia: an anonymous crosssectional questionnaire study in 2017-18. Sex Health. 2020;17(1):53-60.

19. Ma Q, Jiang J, Pan X, Cai G, Wang H, Zhou $\mathrm{X}$, et al. Consistent condom use and its correlates among female sex workers at hair salons: a cross-sectional study in Zhejiang 
province, China. BMC Public Health. 2017; 17(1):1-12.

20. Gharehghani MAM. Barriers to condom use among female sex workers in Tehran, Iran: a qualitative study. Int $\mathrm{J}$ Womens Health. 2020;12:681.

21. CDC. Condoms [Internet]. 2021 [cited 2021 Sep 15]. Available from: https://www.cdc.gov/hiv/basics/hivprevention/condoms.html

22. Basuki E, Wolffers I, Devillé W, Erlaini N, Luhpuri D, Hargono R, et al. Reasons for not using condoms among female sex workers in Indonesia. AIDS Educ Prev. 2002;14(2):102-16.

23. Magalhães R de LB, Sousa LRM, Gir E, Galvão MTG, Oliveira VMC de, Reis RK. Factors associated to inconsistent condom use among sex workers. Rev Lat Am Enfermagem. 2019;27.
24. Duff P, Birungi J, Dobrer S, Akello M, Muzaaya G, Shannon K. Social and structural factors increase inconsistent condom use by sex workers' one-time and regular clients in Northern Uganda. AIDS Care. 2018;30(6):751-9.

25. Januraga PP, Mooney-Somers J, Gesesew HA, Ward PR. The logic of condom use in female sex workers in Bali, Indonesia. Int $\mathbf{J}$ Environ Res Public Health. 2020;17(5): 1627.

How to cite this article: M.Akbar Alwi, Hamzah H, Mahfudah U. Sexual behavior of female sex workers in Makassar, Indonesia. International Journal of Science \& Healthcare Research. 2021; 6(3): 460-465. DOI: https://doi.org/ 10.52403/ijshr.20210774 